\title{
ESBOÇO DE UMA IDENTIDADE TRANS NO SÉCULO XIX: la Fille manquée, de HaN RyNer
}

\author{
Han Ryner's La Fille manquée: outlining a \\ trans identity in 19th century
}

\author{
Régis Mikail Abud Filho ${ }^{1,2}$ \\ ${ }^{1}$ Universidade Paris-Sorbonne. Paris, França. \\ ${ }^{2}$ Universidade Livre de Berlim. Berlim, Alemanha. \\ E-mail: regismikail@gmail.com
}

\section{RESUMO}

Como a identidade trans era representada na ficção durante a passagem do século XIX para o século XX? A literatura científica e os modelos de sexualidade sequer a reconheciam, limitando-a à categoria de "homossexual". O romance La Fille manquée (1903), de Han Ryner, questiona essas teorias ao ressaltar a complexidade da natureza e da sexualidade humanas. Sob esse escopo, propomos uma interpretação da protagonista François ("a menina falhada" do título, termo atribuído ao homossexual masculino) e de seu sofrimento como incapacidade em assumir plenamente sua identidade feminina, indicada em vários pontos da narrativa. Para tal, recorremos aos discursos (pseudo)científicos do século XIX, então em voga, e a estudos de Freud, notadamente sobre Da Vinci e o conceito de narcisismo, considerando a estrutura do romance, a construção da personagem e o contexto literário da época.

PALAVRAS-CHAVE: identidade trans; literatura científica; homossexualidade; século XIX; Freud; narcisismo.

\section{ABSTRACT}

How was transexual identity represented in fiction during the turning to the 20th century? Hardly recognized by so called cientific literature and modalities of sexuality, trans identity was restricted to the "homossexual" category. Han Ryner's novel, La Fille manquée (1903), questions such theories, by underlining the complexities of human nature. From this scope, we propose here an interpretation of its main character, François ("the failed girl" from the title, an expression designating the male homosexual) and his/her suffering as being incapable of fully conceiving his feminine identity, indicated in many parts of the narrative. For such, we refer to (pseudo)scientific discourses of the 19th centuries, which are reviewed by the author, and to studies by Freud, namely about Leonardo Da Vinci and the concept of narcissism, considering the structure of the novel, the character construction and the literary contexto of that time.

KEYWORDS: trans identity; scientific literature; homosexuality; 19th century; Freud; narcissism. 


\section{LA FILLE MANQUÉE E A ATUALIDADE}

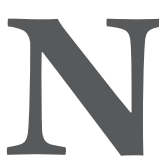

o romance La Fille manquée ${ }^{1}$ observa-se a visão libertária e emancipatória de Han Ryner (18611938), escritor anarquista e pacifista, cuja originalidade revolucionou ideias socioculturais e literárias no século XIX na França. No Brasil, a divulgação e tradução de sua obra deve-se em grande parte a Maria Lacerdes Moura, que, inspirada pela verve libertária de Ryner, repercutiu em seus textos autorais ideias transgressivas para a época, como o amor livre e a emancipação da mulher. Como então explicar a escassez de estudos, tanto no Brasil quanto no exterior, sobre La Fille manquée, narrativa que aborda uma psique não-hétero e não-cis, conforme propomos analisar aqui?

A expressão fille manquée (literalmente "menina falhada" ou "menina que não vingou”) conota, em língua francesa, o homossexual masculino atribuindo-lhe uma identidade de gênero feminina, algo aproximadamente traduzível como "a menina que não vingou" ou, ainda, nos termos "mulherzinha", "bichinha", "mariquinha”, que soam mais pejorativos em português devido à presença do sufixo diminutivo feminino, em uma clara depreciação machista e androcêntrica.

A publicação do romance em 1903 escandalizou a França por escancarar a homossexualidade masculina - e, como investigaremos -, uma identidade trans. O lirismo verbal de Ryner prenuncia conceitos que serão posteriormente desenvolvidos durante os primórdios da psicanálise. Sob à luz de discursos psicanalíticos, estéticos e principalmente literários, propomos uma leitura da representação das questões de gênero, evocadas em uma narrativa que, apesar de certos traços emancipatórios e ensaísticos, apresenta-se sobretudo como obra de ficção.

Por um lado, as conquistas trazidas pelos estudos de gênero e pela teoria queer da atualidade parecem ter relegado La Fille manquée a um lugar obsoleto dessa literatura inicialmente representadora - e hoje já não tão representativa - das identidades homo e trans. Por outro, há justamente nessa representação um aspecto parcialmente negligenciado, e que merece ser trazido à luz: a identidade trans na construção psicológica da protagonista. Ora, a recente republicação do romance em 2013 pela editora francesa GayKitschCamp/Question de Genre, enriquecida por um dossiê explicativo de MarieFrance David de Palacio e Patrick Cardon, atesta um interesse vivaz na problemática do romance. Os poucos estudos sobre a androginia e a psique não totalmente cis da protagonista, François de Taulane, permanecem marginais em comparação à maioria das reflexões sobre La Fille manquée. Focando quase exclusivamente na homossexualidade masculina, esses estudos pressupõem a cisgeneridade de François sem considerar o caráter problemático dessa mesma cisgeneridade. Ora, o fato de a transexualidade ser tratada na literatura do século XIX (aqui subentendido como um período extensível até o início da Primeira Guerra Mundial) de maneira absolutamente marginal e superficial - mais como uma prática eventual de travestimento - não implica que a reflexão sobre transição de gêneros não existisse.

Justamente no anacronismo de uma época em que se desconheciam os estudos de gênero reside a pertinência de La Fille manquée. Do ponto de vista do foco narrativo e do pacto ficcional, o leitor depara-se com a "autoficcionalidade de um outro", já que afirmações de veracidade pelo autor Ryner precedem sua intriga. As (fictícias) memórias de François em primeira pessoa mostram-se atuais em termos literários devido à verossimilhança, tanto na realidade diegética quanto extradiegética do

1 Desconhecendo traduções do romance para o português, propomos traduzir o título do romance, La Fille manquée, epíteto da protagonista, como A Maricas, no feminino mesmo. 
romance. Ryner constrói um mapeamento do desejo e da identidade de gênero ao traçar as incertezas da personagem, ora sugestionando ora esmiuçando sua realidade psicológica. Embora as descrições do desejo da protagonista sejam expressadas na primeira pessoa, considerado sui generis para a época, Ryner se abstém de qualquer laivo de julgamento, deixando a entender que a sexualidade e natureza humanas são mais complexas do que aparentam ser.

Seria então "permitido" a Ryner, no contexto contemporâneo, escrever sobre uma identidade sexual e de gênero que não correspondesse à sua, ou seja, como homem, heterossexual, cis e branco? Conceitos como "leitor sensível" e "lugar de fala" espocam na crítica literária atual, de modo que se indaga: com que propriedade um autor heterossexual poderia descrever os desejos e apossar-se da identidade, da psique e de uma luta que ele supostamente desconhece? Por mais complexa que seja a relação de Ryner com o amor ${ }^{2}$, é importante salientar que ele, em sua personalidade progressista manifesta nos gêneros literários que exerceu, defendeu veementemente todas modalidades de amor, ato de coragem incomum para seu tempo, e que será relevante para as reflexões atuais sobre práticas sexuais e identidades de gênero.

\section{A IDENTIDADE DE FRANÇOIS: O CONTEXTO MÉDICO E REPRESENTAÇÕES LITERÁRIAS}

Em primeiro lugar, para compreender a problemática suscitada é preciso situar a estrutura da narrativa, dividida em três partes, além de um prólogo e um epílogo. Quando da primeira edição, a livraria L. Genonceaux e Cie., anuncia nos paratextos o sucesso desta "estranha história de um homem que a impotência jogou aos costumes contranaturais" 3 . O comunicado louva a "absoluta sinceridade" e a "ousadia tamanha" do autor, bem como a "tamanha destreza ao envolver com elegância as audácias mais perturbadoras” (RYNER, 1903). No prefácio da primeira edição, já se alegava tratar-se de um manuscrito encontrado: "O manuscrito de François de Taulane, que publicamos ao presente, não contém título algum” (RYNER, 1903, p. 7). Ryner manterá estabelecido o pacto ficcional da suposta autenticidade do documento, redigindo uma nota de rodapé na qual explica que, com exceção da segunda parte (onde as lacunas entre datas do diário indicam o repouso da atividade sexual intensa da personagem), foi preciso retornar "[à] quelas páginas legíveis pela quebra de sua massa compacta, e esclarecendo-as através de diversos artifícios tipográficos” (RYNER, 1903, p. 7). O tom técnico da nota é entretanto interrompido pela citação de um verso de Alfred de Vigny, grafado nas anotações de François - "L'homme a toujours besoin de caresse et d'amour" : "O homem sempre precisa de carinho e de amor" (RYNER, 1903, p. 7), verso que indica certa inocência da personagem e relativiza o olhar sobre suas pulsões. Mais adiante, compreenderemos que por "carícias", termo empregado à exaustão por François, entende-se um amálgama de afeto e sexo, permeados por entrecruzamentos de sensações estéticas, verbais e picturais, evocadas quando o próprio François se enxerga no feminino. Para tal, a crítica psicanalítica freudiana mostra-se pertinente em nossa análise, considerando-se o contexto do romance, além de indicar caminhos para as superações ganhas com as teorias de gênero do presente.

\footnotetext{
2 Ver o verbete "Amour", escrito por Ryner, na Encyclopédie Anarchiste, disponível on-line em http://hanryner.over-blog.fr/article-11314109. html, consultado 23 de março de 2021) ou em FAURE, 2013.

3 In: RYNER, op. cit., n.p. Grifo nosso. Todas as traduções das obras citadas, com exceção das de Freud, são nossas. Nota bene: neste trecho, nossa tradução é quase literal em relação à sintaxe do original. Por que Ryner não formulou, numa construção sintática mais natural, "um homem cuja impotência..." ? Onde se esperava um pronome relativo como "cujo", parece estar subentendido aqui o caráter ativo e incontrolável dessa "impotência”, como se se tratasse de um fator externo, determinado pelo ambiente e pelas condições de vida de François.
} 
Evidentemente alheio à atual possibilidade de redesignação de identidade de gênero, François está condenado a enxergar-se muitas vezes mais como uma fille manquée do que como homossexual masculino, sem no entanto conceber plenamente sua identidade feminina. A diferença entre um François e, por exemplo, o anônimo correspondente epistolar de Zola - um caso verídico de um homossexual napolitano que lhe pediu que publicasse suas cartas confessionais - é evidente nesta questão de gênero. Zola recebe cartas de um homossexual que lhe pede para publicá-las, a fim de tornar sua história conhecida. $\mathrm{O}$ escritor cumpre o pedido. As confissões ambíguas do anônimo, ora orgulhoso e altivo, ora autodepreciativo quanto à sua sexualidade, vem à tona. A literatura médica analisou o caso seguindo os padrões científicos ainda incipientes sobre o tema, ignorando questões de gênero e de sexualidade como as conhecemos hoje. A identidade feminina de François é muito mais clara do que a do correspondente real de Zola, apesar de este ser classificado como inverti-néféminiforme ("invertidonato feminiforme"; LAUPTS, 1910, p. 46). As passagens explicitamente eróticas do correspondente são impregnadas de uma então recente moral laicizante, tão condenatória da homossexualidade quanto a Igreja católica. De fato, as censuras vindas da Igreja perdiam força e tomavam lentamente a forma de supostas patologias científicas, igualmente infundadas. Inclusive, os trechos picantes do correspondente de Zola foram vertidos ao latim pelo pudibundo Dr. G. Laupts, médico analista do caso. Assim, as cartas e os comentários em forma de estudo nos permitem compreender o espírito científico da época e as investigações sobre a sexualidade humana, com o intuito de elucidar a figura do caso peculiar de François na ficção daquele século.

Em La Fille manquée, a percepção de François sobre sua identidade, seu corpo e os corpos alheios permanece enclausurada no campo do imaginário, antecipando as reflexões de Judith Butler sobre a construção de sexo e o desejo, quando tais possibilidades e reflexões apresentar-se-ão epistemologicamente:

[...] para que simplesmente se deseje, pode ser necessário acreditar em um outro eu corpóreo que, dentro das regras de gênero do imaginário, possa adequar-se às exigências de um corpo capaz de desejo. Essa condição imaginária de desejo sempre excede o corpo físico, através do qual ou no qual opera. (BUTLER, 1990, p. 96)

Veremos que François mostra-se perfeitamente lúcido quanto ao objeto de seu desejo. Ele percebe-se, e muitas vezes aceita-se, como feminino e no feminino através da linguagem e do olhar do outro, de modo que nele uma identidade inteiramente masculina ou inteiramente feminina mostra-se impossível.

Em segundo lugar, enquanto situamos os episódios principais do romance nesse âmbito, analisaremos a representação do desabrochar identitário e sexual de François sem pretensão à exaustão literária ou psicológica. A curiosidade do leitor a respeito do desdobramento de sua história é garantida pela técnica de Ryner, cujo texto instiga o desejo de conhecer o percurso psíquico de François, mais do que as peripécias da intriga, apesar de ele já ter anunciado de início seu suicídio. Na construção da mimesis através do foco narrativo de François, a realidade circundante confunde-se com a construção de sua realidade psicológica em suas transformações. Essas transformações vão ao encontro da ressignificação aferidas por Amara Moira Rodovalho ao "tornar-se" da afirmação de Simone de Beauvoir: 
[...] não se cria ninguém, desde o berço, para ser travesti: o "não se nasce, torna-se" da Beauvoir assume um sentido todo particular em se tratando dessa categoria, pois não existe a opção "nascer" para nós, mas tão-somente a opção "tornar-se". Faz diferença a travesti dizer-se "homem" ou dizer-se "mulher" diante das tantas violências a que estará sujeita? (RODOVALHO, 2017)

Com vistas a compreender a identidade trans imperfeita - no sentido de "inacabada" - de François e por que esse devir ao trans não se realiza, não pudemos deixar de parafrasear e citar aqui, o mais resumidamente possível, diversos trechos do romance. Além de procurarmos esclarecer a intriga, faz-se também necessária a reflexão sobre a relação entre homossexualidade e a suposta "patologia" da personagem.

Considerando-se as poucas publicações sobre La Fille manquée, romance à contramão dos discursos médicos do século XIX, nosso questionamento acerca da identidade trans de François permanece à margem dos estudos sobre o texto, salvo algumas reflexões como a resenha de Nicolas Tessé, que não se hesita em referir-se a François no feminino:

\begin{abstract}
A Maricas ["La Fille manquée"] não é nem homossexual [homosexuelle, no feminino] nem travesti [travestie]; transgênero, em rigor, mas sobretudo [está] constantemente por um fio de saber quem ela é, quem ela quer ser, quem ela teria interesse em ser. Han Ryner, ao ter percorrido esse dilema na espiral de peripécias sentimentais de sua personagem, só encontrou solução para esse problema em seu trágico fim. Terrível destino, lamentável, mas que, carregado pela heroica figura daquele que morreu pela liberdade da dúvida, mais do que pela servidão às ideias, nos diz que uma sexualidade feliz é uma sexualidade na brecha, que sabe deixar-se ir através todas as agitações que a atravessarão, tanto as favoráveis quanto as infortunadas. (TESSÉ, 2014).
\end{abstract}

No campo da prática e da performance de gênero, inferir necessariamente a homossexualidade, pré e pós-transição, do indivíduo trans é uma conclusão no mínimo atamancada. No século XIX, entretanto, a associação da condição homossexual à identidade transexual eram amalgamadas. Se a transexualidade foi quase totalmente invisibilizada naquele século, a homossexualidade figurava como patologia entre as teorias fisiognomistas e frenologistas, pseudociências levadas a sério por um Cesare Lombroso, herdeiro de modelos de compreensão da sexualidade humana. Esses modelos baseavam-se na classificação dos modelos de sexo dos séculos passados, lembrada por Ícaro Gaspodini e Jacqueline Gomes de Jesus, e que precediam o "Modelo da diversidade sexual" surgido a partir do século XX.

O primeiro, o "Modelo do sexo único", em vigor até o início do século XIX, vê na mulher uma forma defeituosa e incompleta do sexo masculino (modelo subjacente em La Femme criminelle et la prostituée, de Lombroso); o segundo, existente desde o século XVIII até o princípio do século XIX, alegando ser o sexo feminino diferente do masculino, vale-se desta justificativa para considerar as mulheres incapazes de realizar tarefas supostamente masculinas (GASPODINI; GOMES DE JESUS, 2020, p. 34-35). De modo geral, na ficção e na literatura que aborda o amálgama transexualidade/ homossexualidade, esses modelos de sexualidade ainda se alastravam na representação de ideias - $o$ que, no caso de La Fille manquée, não quer dizer absolutamente que Ryner tivesse recorrido a tal não diferenciação ou com os diagnósticos comumente proferidos em sua obra.

As teorias de Lombroso, diga-se de passagem, são curiosamente concebidas e verbalizadas à maneira da narrativa de ficção, como revelam as leituras dos relatos de suas "descobertas" pseudocientíficas. Efetivamente, elas se apresentarão como "ficções" mais ou menos fantásticas em razão de sua inexatidão 
e de seu caráter pouco científico, se compararmos esses relatos ao rigor da metodologia científica contemporânea (RENNEVILLE, 2013, p. 107). Se há patologia em La Fille manquée, esta prescinde da sexualidade e da identidade de François como uma clorose (doença atribuída às mulheres, também conhecida como morbus virgineus) ou de qualquer outra patologia de cunho mais social do que médico, daqueles males inventados, que não se esquivam de traços misóginos e sexistas.

Porém, François apresenta sintomas de doenças de tipo neurológico ou mental, sem que estas sejam nomeadas. Os traços neuróticos de François e a somatização de sua depressão se apresentam, por exemplo, na síncope (epiléptica?) que ele sofre quando seu amante Davignon morre. A doença não parece decorrer de sua homossexualidade; ao contrário, tem-se a impressão de que comportamentos patológicos o acompanham. Sem controlar seus desejos e incapaz de cumprir sua identidade de gênero, mais do que de realizar sua sexualidade, François adoecerá devido à solidão e à compreensão - ou à própria incompreensão? - de sua identidade.

\section{SUBMISSÃO E DOMINAÇÃO FEMININA: DO FELINO À REINE FRANÇOISE}

La Fille manquée exprime bem o ar daquela Belle époque, bela senão para poucos, na qual androginia, efeminação e homossexualidade masculina vividas às escondidas eram indistintas pelo senso comum. É preciso, inclusive, atentar para não pressupor a identidade transexual de François a partir de sua efeminação, em base na teoria de gêneros. Assim, termos como "pederastia” ou "terceiro sexo" (a exemplo do livro homônimo de Willy) são atualmente considerados inexatos, mas eram frequentes na literatura médica e de ficção. Revelam, no caso de François, o aspecto mais passivo do sentimento amoroso, uma identificação com a suposta submissão feminina de François em sua tentativa fracassada de experiência sexual com a prima Lisa depois de ter se relacionado com rapazes:

Soube depois que há uma outra carícia viril além daquelas que eu via. Jean Provençal [...] que é [...], mais do que a própria Lisa, o operário de meu destino, não deixou que eu ignorasse nada. Impôs a mim o abraço terrivelmente doloroso que esquece que a maricas não é absolutamente uma mulher, que o namorado quase namorada não tem órgãos da volúpia passiva e que meu corpo não pode ser penetrado senão no sofrimento. (RYNER, 1903, p. 32)

Observa-se uma clara identificação de François com o estereótipo feminino submisso da época. É na violenta demonstração de ciúmes do colega de internato Jean, "maldoso como uma mulher" e amado por ele "como se fosse o bom Deus (RYNER, 1903, p. 121)", que François dá vazão às primeiras pulsões masoquistas. Quando o amante-verdugo Jean ameaça matá-lo, ele pede que lhe deixe sentir "o gosto de suas carícias”. Assim, humilhando a maricas (François), Jean manifesta seu desejo de que ela seja sua escrava. A própria maricas, como quem se vê de fora, responde também na terceira pessoa; refere-se a si mesmo por meio de seu apelido feminino e consentirá alegremente em subjugar-se, em um comportamento que recrudescerá ao longo da narrativa.

Os atos de François não são tratados como perversos no romance. Pode-se observar, ao contrário, certa falta de malícia da infância, momento em que os julgamentos morais ainda não tomaram forma na linguagem poética do narrador em primeira pessoa. Rememorando sua vida com recuo, François evoca no início de suas memórias os efeitos deletérios de sua vivência no colégio interno Saint-Louisde-Gonzague (frequentado pelo próprio Ryner de 1877 a 1879). Intelectual e esteta, ao mesmo tempo 
que é influenciado por certo determinismo filosófico, François afirma não poder escapar do meio que contribuiu à sua formação naquele espaço de atividade sexual intensa (o afã por sexo apresenta-se, aliás, como compensação da não-realização identitária). Através de tal determinismo, transparecem resquícios naturalistas da construção da personagem, conforme suas próprias palavras:

O que poderia ter formado aquele próprio meio? A brandura voluptuosa da região é a culpada? É preciso acusar a imensidão da casa, construída por mil e quinhentos alunos, e as numerosas partes inabitadas, quase desconhecidas, onde se podia errar em liberdade? O diretor deve ser acusado de indulgência criminosa e de otimismo voluntariamente cego, ou era impossível obter algo melhor dos alunos que lhe eram confiados? [...] Os órfãos eram muitos; os filhos ilegítimos [gerados antes do casamento] não eram raros. Não posso esquecer os costumes infames da maioria dos mestres, professores mal pagos, jovens embatinados que a fome havia revestido da libertação eclesiástica, pobres sedentos de amor, cuja miséria, timidez e hábito os exilavam do mundo feminino, e que enganavam como podiam sua concupiscência. (RYNER, 1903, p. 23)

Na passagem supracitada, lê-se que a miséria financeira e espiritual é responsável pela formação do meio, que por sua vez forma as pessoas. A fome é o agente, como lemos acima; essa mesma fome, agente que "havia revestido os jovens da libertação eclesiástica", por exemplo, em uma construção verbal pela mesma sintaxe aqui apontada no início (a impotência de François que o levara à sua desgraça). Mais adiante, François explicará melhor essa concupiscência onipresente no colégio:

[...] a Instituição Saint-Louis-de-Gonzague era um asilo de carícias viris, uma cloaca de alegrias ignóbeis. Por toda a parte, atrás dos vastos plátanos dos pátios imensos; em estudo, às escondidas das carteiras elevadas; em toda sorte de canto perdido, trocavam-se beijos o dia todo. À noite, o dormitório vivia de uma infame vida sussurrante e tateante. (RYNER, 1903, p. 23-24)

Neste escopo determinista, os termos mais recorrentes no romance serão, de fato, "carícias" e "alegrias”, únicas formas de compensação possível para a desolação: "Os pueris amores [da cidade] de Reber eram fáceis e delicados, sem crueldade para o fraco. A experiência de meus olhos não tardou a expressar-se assim em minha mente: 'Existem duas carícias. Na primeira, a mão colhe uma flor de alegria. Na segunda, é a boca que está contente e que faz contente (RYNER, 1903, p. 32).” Não obstante a repetição obsessiva das "carícias", subterfúgios do próprio narrador para evitar termos mais explícitos referentes ao âmbito erótico, o lirismo do olhar de François sobre seu passado faz-se verbo na mente que concebe as palavras e na boca que as profere; na mente que imagina amores e na boca que os realiza.

O lirismo tomará proporções sinistras já anunciadas no início do romance, ou seja, o suicídio de François. Ele examina suas atitudes pregressas de tal modo que o leitor, a princípio, tem a impressão de estar diante das confissões de um padre:

Creio ver um monge que, em uma célula quase sem móveis, medita. Está sentado sobre uma cadeira de palha, diante de uma mesa de madeira branca.

Em um canto, a cama espera seu próximo sono [...]. Esse monge tem meu rosto delicado, imberbe, feminino, e sob o hábito grosseiro que uma corda enlaça na cintura, agita-se a flexibilidade frágil de meu corpo. Esse monge sou eu mesmo. (RYNER, 1903, p. 7) 
Logo se percebe que a figura eremítica não é um religioso, e sim de homem de natureza feminina. Encerrado em sua biblioteca "povoada por móveis de rostos sorridentes e voluptuosos, [...] biblioteca que, sem os livros, pareceria um gabinete um grande demais (RYNER, 1903, p. 18)", esse espaço, assim como o isolamento e a hipersensibilidade estética explicam o caráter literário de François, tão marcante quanto seu amor pelas artes plásticas que analisaremos adiante.

Logo após esta descrição situacional, seguem-se retrospectivamente as memórias da primeira parte de La Fille manquée. Nela, aborda-se a infância do órfão François, confiado aos cuidados dos tios. Ele havia encontrado acalanto na figura paterna após a morte da mãe ao dar-lhe à luz. A recordação materna, "de ares reais", inspira-lhe medo (RYNER, 1903, p. 10). O pai morrerá em seguida, e durante os carinhos dúbios com o tio que o adotará, François ver-se-á como um "felino" em busca carícias escondidas, manifestação precoce de androginia e animalidade de um desabrochar de sua sexualidade:

Quando não nós arriscávamos ser surpreendidos, [o tio] não parecia surpreso, nem por meus primeiros relares de pequeno felino selvagem, nem pela aspereza repentina com a qual eu me lançava sobre ele e o escalava em ataque de beijos. Ele me restituía carinho por carinho. Bruscas lágrimas afundavam meus olhos, e ele as enxugava, quase sem ralhar comigo. (RYNER, 1903, p. 11)

Em sua manifestação sexual instintiva precoce, a vivência sexual de François esboçar-se-á como uma busca de carícias, já que a esposa do tio, Désirée, e as primas, Louise e Lisa, só lhe reservavam humilhações:

Minhas primas pouco gostavam de mim. Louise [...] protestava gritando contra qualquer movimento que eu fizesse, me empurrava, me batia. [...] Lisa [...] tinha mais ou menos a minha idade, e sua visão era para mim uma emoção sempre nova, pois não se poderia conceber beleza mais surpreendente. Seus traços lembravam-me os de minha mãe; tinham algo de definido, de finalizado, que, ao que parece, poderia machucar em uma criança [...]. Mas aqui havia mais do que algo simplesmente completo; havia um tanto de paradoxal harmonioso; havia um encanto altivo bastante difícil de se expressar. (RYNER, 1903, p. 11)

Em suas reflexões, François projeta, não sem certa misoginia, sua identidade feminina na figura cruel atribuída à mulher, pois mostrar-se-á dominador e altivo como Lisa no campo da satisfação de suas carícias com os rapazes. Por exemplo, no fim de sua história, ele se alegrará ao ver o motim causado no internato, ao observar os meninos brigando para colocarem seus nomes na lista onde estão assinalados aqueles que receberão seus afagos. A transição psíquica de François, em sua identificação com o feminino conforme à sua vivência, atravessará sempre essa representação da femme fatale de Lisa e de sua mãe, em contraste com sua índole angelical.

Após a morte dos pais e a adoção provisória pelos tios, antes de confiar François ao colégio interno, o tio leva o menino à casa de tia Mélie. Semelhantemente à personagem proustiana tia Léonie, ela vive acamada entre as janelas de seu quarto sombrio, açambarcado de velharias. Suas palavras proféticas serão relembradas por François em sua solidão: "Meu pobre François, [...] você se assemelha a mim" (RYNER, 1903, p. 15). A enclausurada vive em um mundo no qual não se encaixa, tal qual François: os médicos a haviam mandado para uma região de clima ameno meridional, mas ela não consegue viver de janelas abertas, pois o sol, "vilão" e "gritalhão" (RYNER, 1903, p. 15), é forte demais. Nem mesmo se ela estivesse em Paris poderia estar à vontade devido ao clima ríspido. François também deparar-se-á com os mesmos problemas nos espaços geográficos - e psicológicos - de sua vida. 
No primeiro encontro, tia Mélie prejulga mais uma suposta semelhança entre ambos: "François é como eu, não gosta de carícias” (RYNER, 1903, p. 15), o que, bem se sabe, revelar-se-á inexato. No meio da penumbra do quarto, ele percebe na luz um "angorá soberbo", identificando a si mesmo como carinhoso e ao mesmo tempo arisco:

Sem parar de ronronar, veio até sua dona, escalou relando até o ombro e, esfregando a cabeça contra as bochechas da solteirona, afundou seu focinho em direção ao de tia Mélie. O sensibilíssimo focinho, para o qual o mínimo contato humano era penoso, voltou-se acolhedor, alongou-se em uma careta feliz. Trocaram um beijo, também um olhar de amor. Verdadeiramente, sim, naquele segundo os olhos ternos de tia Mélie tiveram o brilho de um olhar. (RYNER, 1903, p. 15)

Em consonância com o determinismo refletido na estética naturalista, o ambiente geográfico também exerce influência sobre François em suas reflexões, cuja morbidez confirma certas impressões da tia acerca de sua insatisfação:

A beleza da região comovia-me cada vez mais e satisfazia-me cada vez menos. Eu estaria cometendo um erro, uma espécie de insinceridade, se agrupasse em descrições os detalhes dos quais eu gostava. Uma descrição é algo claro, estável, fixo, um pouco pesado, e meu amor por aquela terra foi sempre uma inquietude. (RYNER, 1903, p. 24)

No internato, François cai nas mãos do diretor, o abade Saurien. Ali se travavam aquelas "amizades particulares" (RYNER, 1903, p. 25), que desempenharão o mesmo papel do tio em sua vida afetiva pré-adulta, a saber, carícias de "felino":

Depois [da partida de tio Bertrand] eu suspirava, um pouco porque ele não estava lá, mas sobretudo porque eu não ousara [distribuir] as carícias íntimas que tio Bertrand me permitia: eu não ousara saltar em seu pescoço e alegrar meus lábios contra suas bochechas; sequer ousara relar seu corpo com meu corpo felino [...]. (RYNER, 1903, p. 19)

De fato, as crianças rebeldes, os professores desinteressados e o bedel odiado pelos internos lhe trazem à memória a crueldade das detestáveis primas e de tia Désirée, em uma espiral sem fim de projeções confusas. Sobretudo Lisa, que o beliscava até fazê-lo sangrar, era a mais amada por ele por ser mais sádica: uma verdadeira esfinge "indecifrável” (RYNER, 1903, p. 58), com sua "fisionomia que mente” (RYNER, 1903, p. 12). Apesar de ter tentado, François é incapaz de fazer sexo com Lisa, que desempenha papel fantasmático crucial na "transformação" de François em La Reine Françoise, apelido que lhe é dado pelos colegas, evocando o topos da mulher cruel, recorrente no tardo século XIX, a exemplo do mito bíblico de Salomé por Wilde e Flaubert, entre outros.

\section{SADOMASOQUISMO: UMA CARÍCIA?}

Na segunda parte, escrita em forma de diário iniciado a 11 de abril de 1899, François e Lisa vão passar férias na praia, em uma tentativa de forçar uma história de amor. É o único momento em que ele afirma ter “[s] e sentido viril” (RYNER, 1903, p. 69). Na ânsia de abandonar seu desejo homossexual e sua efeminação, ele chega a acreditar que ama Lisa, mas logo depois se desengana. Mesmo tendo exercido vigorosas atividades sexuais com a prima, a insaciabilidade da moça acaba exaurindo a saúde frágil de François, que ficará acamado por dias. Nesse período, o mais doloroso segundo suas descrições, 
Lisa é descrita como belíssima. Trata-se, entretanto, de uma beleza platônica, de um desejo cerebral. "Soberana" e "altiva" (RYNER, 1903, p. 57), ela sempre havia se apresentado como projeção materna de François:

[...] tal como o sorriso por vezes modifica o sentido das palavras pronunciadas, certos rostos são envolvidos por uma inexprimível atmosfera que muda toda sua expressão. Em suas fotografias, Lisa só expressa altivez e desdém. Mas, na vida, como o olhar desmente deliciosamente os olhos, como o sorriso declara os lábios mentirosos, como a luz por ela emanada proclama que todo aspecto engana! (RYNER, 1903, p. 12)

Eis que François se dá conta de sua natureza feminina: “4 de maio - Essa noite eu tentei... Oh! fui modesto, não tive a presunção de querer ser um homem. Eu tentei, como dizer?... ser uma mulher que ama uma outra mulher. Lisa me repeliu: 'Não, isso não!'” Naquele momento histórico, convém lembrar, não se costumava conceber a homossexualidade nem a bissexualidade trans. De início, François parece contudo mais bissexuado do que propriamente bissexual, procurando adaptar-se às circunstâncias do meio, sem êxito: "Um outro satisfará [a esperança de Lisa]: os braços viris não são nada raros. Quanto a mim, encontrarei alguma vez uma mulher que se satisfaça com o amor da 'maricas'?" (RYNER, 1903, p. 68)

Até então, as carícias com os colegas de internato eram consideradas brincadeiras por ele, apesar dos desdobramentos sadomasoquistas. Jamais a palavra "sexo" é empregada no texto em referimento às experiências futuras de François. Porém, se por um lado François conseguirá reconhecer sua natureza homossexual, por outro, relutará em aceitar plenamente sua identidade feminina, permanecendo confinado na incerta condição de "maricas". Essa identidade feminina alinha-se mais ou menos ao que a sociedade burguesa esperava de uma mulher: uma docilidade, com a qual François jogará invertendo papeis de dominação e submissão, em uma performance de dominação e autoridade quando das carícias com os colegas.

$\mathrm{O}$ ponto de vista de François sobre as mulheres, cuja misoginia corresponde à própria autodepreciação, já se manifestava em frases soltas durante sua infância. Assim, ao ter afirmado que “[a]s mulheres nunca têm coração” (RYNER, 1903, p. 12), ele levou uma palmada de tia Désirée. A esta lembrança de François segue-se um questionamento intelectual sobre o masoquismo e o desejo, em um total rechaço das impressões pré-românticas de Rousseau em Emílio, cujo vulgar masoquismo ele censura:

Eu não tinha aquela rude e precoce virilidade de Jean-Jacques Rousseau, aquele plebeu, aquele valete. Não experimentava volúpia alguma ao levar palmadas de uma mão feminina. É ainda com sentimento de ódio e de terror que me revejo, pobre ser que se agita sob um braço da gigantesca e ossuda criatura. Sinto ainda os golpes caírem sobre mim, regularmente, e o vermelho da ira sobe até meu rosto. (RYNER, 1903, p. 12)

Embora não as formule em termos científicos, sociológicos ou psicológicos, as impressões de François sobre si mesmo se realizam nas palavras e no jogo poético, processo que Amara Moira Rodovalho caracteriza como "negociação tensa de sentidos": "[...] a auto-identificação não dá conta de resolver o caso, visto que o papel que a pessoa desempenha no mundo não é decidido de maneira unilateral, por decreto, mas sim através duma negociação tensa de sentidos entre o que é ser e o que 
é parecer (RODOVALHO, 2017).” Precisamente a dicotomia vivida por François - ser e parecer - o levarão a uma problemática aceitação de si como "maricas", isto é, como identidade feminina incompleta, acarretando seu desespero final.

A questão do desconforto no gênero masculino quase não é formulada pela personagem, embora sua obsessão pelo feminino esteja corroborada; culpam-se as circunstâncias ambientais. Definida como "fraqueza", a patologia de François, espécie de fleuma, é muitas vezes por ele explicitada como "sentimento" patológico - e não exatamente como uma patologia em si. François se questiona se essa impressão constitui "o sentimento de [sua] fraqueza e também o ardor de [s] eu desejo" (RYNER, 1903, p. 26). Na verdade, o sentimento patológico que François vê em si provém de uma pronunciada hipersensibilidade à arte: "Quando leio versos em voz alta para mim mesmo, se uma passagem me toca, me entusiasma, se minha língua, paralisada pela alegria literária, de repente se põe a gaguejar, suspeito que se minhas ações gaguejaram, é porque sou um apaixonado" (RYNER, 1903, p. 26). As sensações estéticas que as artes plásticas também provocam em François eram comumente atribuídas às mulheres e aos "invertidos" de acordo com a medicina da época: essa é a ideia central de Dr. Laupts em sua classificação da homossexualidade, ao analisar o caso do mencionado correspondente de Zola.

Tanta sensibilidade se opõe à maneira distinta pela qual François percebe as coisas diversamente de seus colegas, o que explica sua percepção inicial naquele momento como feminino, especificamente como aquela declinação feminina (e no feminino) que fazia François detestar e ao mesmo tempo admirar figuras de mulheres: "Por outro lado, eu estava desorientado, inquieto por causa da falta de sequência das palavras e dos atos de meus colegas. Ora frases e gestos balbuciavam amor; ora tudo gritava raiva ou inveja. Eu era o mais rico e, senão o mais belo, ao menos o mais femininamente bonito" (RYNER, 1903, p. 26) ${ }^{4}$. De modo confuso, a identidade de François se constrói verbalmente para si mesmo e para com seus colegas, que passam a escrever frases tanto de amor quanto de ódio nas paredes do internato: “[...] as inscrições exprimiam diretamente, em palavras obscenas, desejos ignóbeis”, uma “perseguição por escrito” (RYNER, 1903, p. 26). Quando escritas, tais vulgaridades eram odiadas por François, o que nem sempre ocorria ao serem proferidas oralmente,

porque eram pronunciadas aos risos; porque diziam, sujas como palavras de comilança, o grosseiro desejo ou a grosseira satisfação dos corpos; porque ignoravam a verdadeira volúpia, a de compreender, através da linguagem do corpo repentinamente iluminado e enobrecido, que nossa alma não está sozinha e perdida no infinito; porque eles tornavam feia e grotesca a mais linda das coisas [...], e a mais profunda, a carícia. (RYNER, 1903, p. 27)

A carga semântica das palavras pichadas, como o próprio narrador relata, tão diversa da poesia lida em voz alta, é percebida como integrante das aventuras sexuais, já que o próprio desejo de François muitas vezes consiste mais em uma aventura poética do que sexual. Por exemplo, quando François se esquiva de certo movimento na companhia de outro rapaz, este protesta: “- Malvado!, esbaforiu [o amante] ofegante, malvado e bobo! É tão gostoso, sobretudo quando a gente se gosta! A palavra sobretudo me despertou, me fez saltar, como o contato de algum imundo bicho gosmento: - O que está dizendo?, gritei. Como! Mesmo sem me amar..." (RYNER, 1903, p. 40), revelando assim a importância extrema da linguagem para a personagem.

4 Grifo nosso. 
A ingenuidade - talvez recusa inicial em reconhecer-se como homossexual? - manifesta-se na nomenclatura atribuída a François, que no entanto também revela certa lucidez precoce ao analisar não somente a posição da mulher, mas também a suposta degradação que a presença do feminino no masculino pode provocar. Assim, refletindo sobre os privilégios dos homens (cisgêneros e heterossexuais), conclui: "É notável que essa moral, regendo relações unissexuais, se assemelhe bastante, no entanto, à moral atual que admira Don Juan e despreza a mulher fácil” (RYNER, 1903, p. 68). Ora, o que é François, segundo ele próprio, senão uma "mulher fácil"? Com qualificativos pejorativos, ele observa a atribuição assertiva que os internos dão a Romanes, seu primeiro amante: "Eu ouvia repetir ao meu redor que Romanes, femininamente infame, era covarde como uma mulher. Sua feiura robusta pareciame a vestimenta necessária da covardia” (RYNER, 1903, p. 35). Embora demonstre noções precoces sobre a desigualdade de gêneros, François não ousa contestá-la, e se vê como desprezível devido à mesma semelhança reconhecida, ou que acredita reconhecer, no feminino com o qual se identifica.

Colocando-se no extremo da submissão, a protagonista percebe a intensidade das primeiras carícias com Romanes e se transforma naquilo que Freud viria a classificar como perversão masoquista, identificável sobretudo nas mulheres:

Para começar, parece haver confirmação do ponto de vista de que o masoquismo não é a manifestação de um instinto primário, mas se origina do sadismo que foi voltado contra o eu (self) - ou seja, por meio de regressão de um objeto para o ego. Pode-se ter como certo que os instintos com propósito passivo existem, particularmente entre as mulheres. A passividade, contudo, não é a totalidade do masoquismo. A característica do desprazer também pertence a ele - um desconcertante acompanhamento para a satisfação de um instinto. A transformação do sadismo em masoquismo parece dever-se à influência do sentimento de culpa que participa do ato de repressão. (FREUD, 1919, p. 244-245)

Sem ter plena consciência de sentimentos de culpa, François deleita-se com agressões, principalmente quando o agressor é belo. Regida por palavras, gestos e traços, o masoquismo se apresenta mais como fenômeno psicológico marcado pela impressão estética do que na fisicalidade do ato sexual:

Nas lutas entre crianças, os punhos e os pés são as únicas armas admitidas. Eu utilizava também as unhas e os dentes. Eu recebia mais golpes, e os mais violentos; meu agressor tinha quase sempre o rosto e as mãos ensanguentados. Havia uma exceção. Se meu inimigo fosse muito bonito, eu não ousava estragarlhe o rosto e recebia os golpes em uma paralisia alegre, quase como carícias. E, quando ele me deixava, eu voltava a provocá-lo, sem machucá-lo: eu tinha necessidade de renovar meu êxtase assassinado. Meus ordinários procedimentos de defesa faziam dizer que eu era "traidor" e "mau como uma mulher"; eles também, ao que parece, justificavam o apelido de “a maricas”. (RYNER, 1903, p. 36)

O gosto pela violência, um certo misticismo vago e uma complacência para com o carrasco satisfazem François, inclusive em demonstrações de violência. Assim, resignado como um santo torturado perante o carrasco, somente as agressões de seu futuro amante Davignon, rapaz mais velho e tuberculoso, parecem despertar nele a libido incontrolável. O desejo sexual cresce em François, sensorialmente expresso junto a busca de um afeto como o que obtivera do tio: "[Davignon] era um homem feito. Um bigode já cobria seu lábio, e mesmo a barba emoldurava o quadro demasiado preciso. 
Aqueles pelos eram de um preto intenso junto à excessiva palidez da pele. Ele comovia-me como um ser muito forte e como um ser muito frágil” (RYNER, 1903, p. 42). Assim como ocorrerá com François, a entrega aos prazeres excessivos prejudicará tanto sua própria saúde quanto a de Davignon: "Mas um dia desses, pelo menos assim me pareceu, seu corpo, corroído por alegrias demasiado frequentes, por contínuas descargas nervosas, cairia para nunca mais erguer-se. Um desejo trêmulo me atraía nele” (RYNER, 1903, p. 42). Nessa relação com o moribundo, François nutre a fantasia de ser sua mulher - nos sentidos de "fêmea" e "esposa", uma espécie de Eva fundida no estereótipo feminino da época expressa por certo misticismo caro à época:

Sim, meu Deus, eu O amo. O Senhor é soberanamente bondoso e soberanamente amável. Não ouve as palavras que Lhe digo subirem até você como carícias? Não tenho outras carícias para Lhe oferecer, já que sou jovem demais para comungar. Mas, ver Davignon e comungar, eis as únicas carícias que desejo. Pois eu $\mathrm{O}$ amo, oh meu Deus, acima de todas as coisas, e amo Davignon pelo Seu amor, que o fez à minha imagem e semelhança. (RYNER, 1903, p. 50)

Estando Davignon irrecuperavelmente adoecido, o luto por sua morte não impedirá os colegas de caçoarem de François: “A maricas é uma viúva, a maricas é uma viúva!” (RYNER, 1903, p. 52). Espumando pela boca, François desfalece, para depois concluir: "As palavras que ninguém mais pronunciava, eu ainda as ouvia. Mas agora elas nada tinham de hostil. Vinham de mim, como uma verdade reconhecida. Eu acolhia-as quase como amigas severas" (RYNER, 1903, p. 52-53). Seria essa "verdade reconhecida" a percepção de si, algo impossível de se realizar ou até de compreender: ser mulher?

\section{A BRUMA E O ESPELHO DE BOLSO: NARCISISMO E A PINTURA DE DA VINCI}

Se, por um lado, no primeiro capítulo da primeira parte, François é descrito como possuído por um desejo eufórico, “[d] obrado sobre [si] mesmo, inteiramente ocupado em reviver seu dia como um primeiro capítulo de romance, e a prolongá-lo em todas as direções de alegria” (RYNER, 1903, p. 11), no sexto capítulo, ainda à guisa de preâmbulo, a psique François é detalhada.

Na tentativa de entender a si mesmo pela escrita em primeira pessoa, passando pelas sensações evocadas pela arte, os relatos de François reverberam influências do decadentismo em sua apreciação estética das artes. Ele perambula entre museus, estabelecendo paralelos entre sua vida e a arte, refletindo sobre a beleza física das personagens representadas em pinturas. Ao redigir suas memórias, François menciona "a semiobscuridade flutuante da primeira meia-hora, na total obscuridade que seguia a impressão de que um mistério [o] cercava” (RYNER, 1903, p. 21). Na descrição verbal do tempo e do espaço como um claro-escuro, evoca-se um duplo mistério, místico e sexual. O primeiro aspecto, já esboçado quando da morte de Davignon, se manifesta em François por meio de visões psico-estéticas, como referencial feminino de experiência mística em sua "paradoxal alegria"; o segundo é representado como projeção de seu desejo que atravessa a percepção do feminino, não só como "imaginação de mulher" nos dizeres do próprio François, mas também interpretável como imaginação de si mesmo como mulher: 
À noite, meu pensamento deitava-se com Carminé. Eu o chamava baixinho: "Carminé, oh! Carminé..." Se a visão chegasse dócil, eu me adormecia com a boca entreaberta por um sorriso, as mãos fechadas sobre uma esperança. Mas meu desejo, devo confessá-lo, não era mais fiel do que uma imaginação de mulher. [...] Certas noites, Davignon vinha espontaneamente, ou quase, perturbar-me com censuras que me faziam chorar e que me abatiam em uma paradoxal alegria. (RYNER, 1903, p. 100)

Como no episódio da morte de Davignon, nos sentimentos de François como mulher e em toda sua duplicidade místico-sexual, observam-se oscilações de humor e sede de experiências, elementos identificados pela antropologia criminal de Lombroso como manifestação de histeria feminina:

\begin{abstract}
Sua característica mais saliente é o erotismo. É verdade que alguns autores afirmam o contrário: [...] [as histéricas] se entregam ao homem por espírito de aventura, por necessidade de emoções imprevistas ou por lampos de paixão mais fugidios do que violentos: mas o que quer que seja, observo que aqui o elemento sexual ainda é latente; ademais, se realmente muitas são apáticas, outras são muito excitadas. Já, entre as 83 histéricas de Legrand, descubro que $12 \%$ se prostituem sem necessidade [...]. (LOMBROSO, 1895, p. 504)
\end{abstract}

Pois, exausto de uma "prostituição sem necessidade", entregando-se a quase todos os rapazes do colégio inscritos na lista da Reine Françoise, esta acaba adoecendo. Mas sua motivação subentendida não se explica tanto pela ordem psicossexual de um Lombroso, mas sobretudo pelo desejo de identificar-se com a mulher, passando pela tal "prostituição sem necessidade". Assim, o desejo de reconhecimento de sua natureza feminina concretiza-se na atividade sexual, que por sua vez consiste mais em uma sede de "carícias" do que propriamente uma ninfomania. Incapaz de cogitar a realização de si no gênero feminino, a maricas encontra-se em uma zona cinzenta e enevoada de sua psique, preso entre duas pressões: a social, que implica ser um homem cis heterossexual, e que inclusive se lhe mostra fisicamente impossível (vide a exaustão sentida após algumas noites de sexo com Lisa) e a pressão de ser um homem cis homossexual, algo socialmente impossível de se concretizar. Mas - e esta é a sutileza da escrita literária de Ryner - nenhum diagnóstico de observação psicanalítica se mostra definitivo. A "menina falhada" do título é o próprio paradoxo ambulante das alegrias graves que François/Françoise declara sentir.

De fato, esses espaços psicológicos cinzentos e misteriosos, evocados pela imagem misteriosa de brumas através de rochedos, remetem diretamente ao espaço geográfico ao redor do internato. François perambula entre formações lacustres, na região de Mourres. Os passeios, "como [suas] primeiras horas de dormitório, eram estranhos fremidos" (RYNER, 1903, p. 25), e os movimentos da bruma através das rochas lhe sugestionam angústia, e ao mesmo tempo evocam o fundo de duas pinturas de Da Vinci: os andróginos Baco e São João Batista (Figuras 1 e 2).

Em sua condição de efebo em busca de "carícias" cis e másculas, François observa: "[...] os maravilhosos andróginos de Da Vinci, Baco e São João, são femininos demais para mim. Amo-os como retratos daquilo que posso dar, e não como retratos daquilo que eu gostaria. Entretanto, eu não voltei às carícias viris. Não quero voltar a elas" (RYNER, 1903, p. 99). Os dois quadros admirados por François e com os quais se identifica são, no que diz respeito ao desejo, desprezados por se assemelharem a ele. Ambos evocam também um mistério não compartilhado, "um segredo de amor", segundo a análise de Freud a respeito deles:

5 Grifos nossos. 


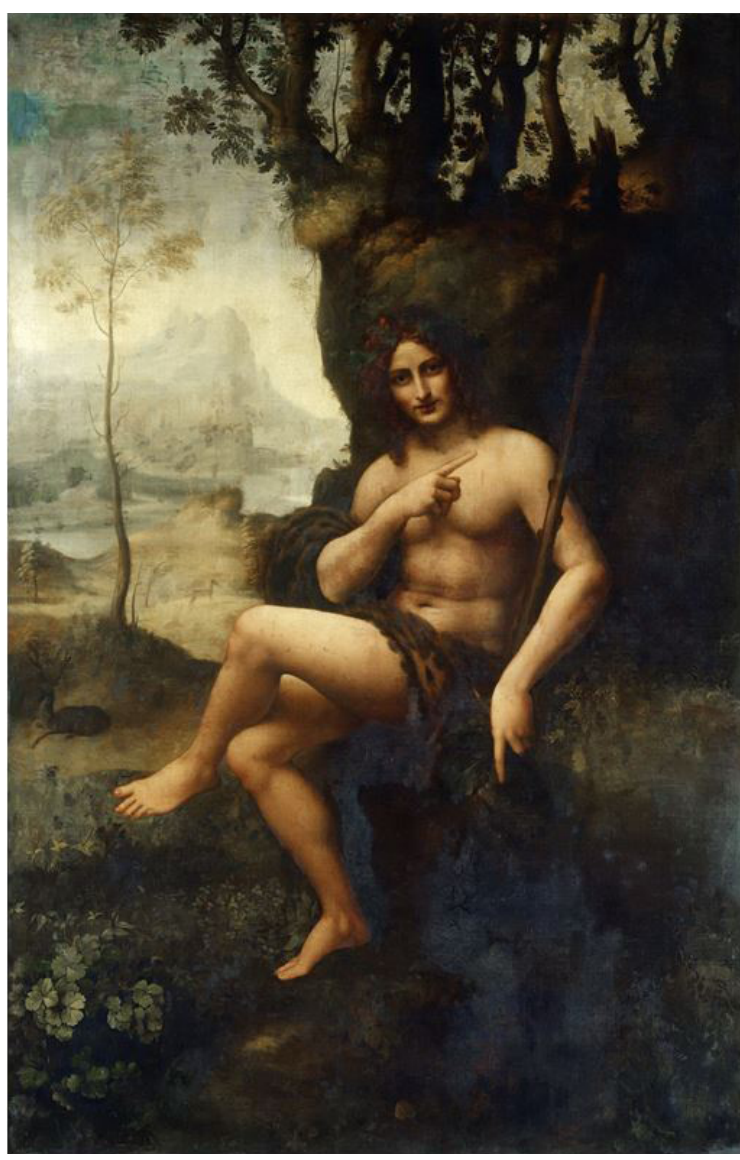

Figura 1 - Baco, Leonardo da Vinci, 1510-1515 (Museu do Louvre, Paris).

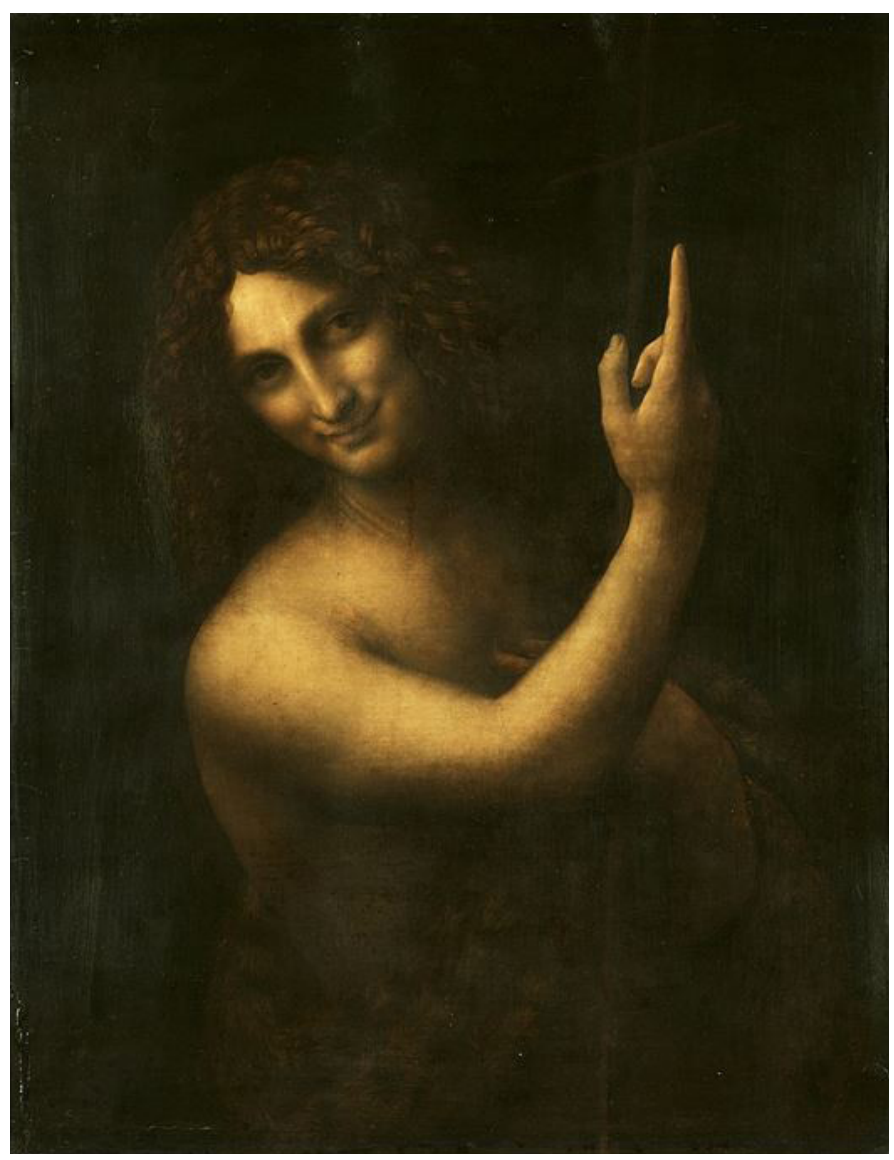

Figura 2 - São João Batista, Leonardo da Vinci, 1513-1516 (Museu do Louvre, Paris).

Esses quadros transmitem um misticismo cujo segredo ninguém ousa desvendar; o máximo que poderíamos tentar seria determinar a sua relação com as criações anteriores de Leonardo. As figuras ainda são andróginas [...]. São jovens lindos, de uma delicadeza feminina e de formas afeminadas; já não abaixam os olhos mas contemplam-nos com uma expressão de misterioso triunfo como se conhecessem uma grande felicidade cujo segredo devessem calar. O sorriso fascinante e familiar leva-nos a crer tratarse de um segredo de amor. (FREUD, 1910)

Nota-se aqui outra semelhança entre os quadros e o próprio François: o orgulho transparecido nos sorrisos, que sugere ao espectador um mistério delineado sob a forma etérea do desejo homossexual. Afinal, de que ou de quem riem os retratos desses personagens divinos? Se trouxermos o sorriso observado por Freud para o contexto de La Fille manquée, pode-se traçar uma identificação com a identidade andrógina de Baco e São João, bem como com a própria identidade trans de François. $\mathrm{O}$ misticismo religioso de ambos não deixa de evocar um mistério presente tanto no espaço de La Fille manquée quanto na protagonista e nas obscurecidas paisagens rochosas.

Um último aspecto digno de nota sobre o a identificação de François com essas duas pinturas de Da Vinci é a representação do narcisimo, também apontado por Freud em sua análise dessas mesmas obras. Ryner parece desconhecer o conceito de narcisismo tal qual posteriormente desenvolvido por 
Freud, algo no qual este provavelmente já havia começado a trabalhar antes da publicação de La Fille manquée. O conceito de narcisismo já desponta no estudo de Freud sobre Da Vinci:

O menino reprime seu amor pela mãe; coloca-se em seu lugar, identifica-se com ela, e toma a si próprio como um modelo a que devem assemelhar-se os novos objetos de seu amor. Desse modo, ele transformou-se num homossexual. O que de fato aconteceu foi um retorno ao autoerotismo, pois os meninos que ele agora ama à medida que cresce, são, apenas, figuras substitutivas e lembranças de si próprio durante sua infância - meninos que ele ama da maneira que sua mãe o amava quando era ele uma criança. Encontram seus objetos de amor segundo o modelo do narcisismo, pois Narciso, segundo a lenda grega, era um jovem que preferia sua própria imagem a qualquer outra, e foi assim transformado na bela flor do mesmo nome. (FREUD, 1910).

Acerca das impressões estéticas de François e seus objetos de amor, os relatos na terceira parte de La Fille manquée reforçam seu desprezo pelo corpo feminino e por imagens como a de Baco e São João Batista, que evocam a feminilidade. A única androginia apreciada por François, e ainda assim com reservas, é aquela em que prevalece o masculino, a exemplo da personagem Blanche, uma das duas prostitutas que ele frequenta em Paris. Encontrando-a por acaso na rua, François se fascina por ela e a considera uma "deliciosa andrógina”. Assim apresenta-se o único viés possível da realização sexual de François, notadamente através do corpo masculino como objeto. Blanche se deslumbra com o dinheiro de François, mas, impaciente com sua virilidade débil, troca-o pelo másculo professor de música, contratado para dar aulas de piano à moça. Praticamente a mesma situação ocorrera com Titine, a primeira prostituta que François frequentou, e que, num golpe, havia fugido trocando-o pelo cocheiro, também descrito como um homem viril.

Essas impressões permitem estabelecer um paralelo com aquelas de Des Esseintes, o protagonista de Às avessas, de J.-K. Huysmans. Neste romance dito "decadente”, Des Esseintes também é caracterizado pela efeminação atávica em seu caráter fleumático (HUYSMANS, 1884, p. 2), e que nos devaneios de sua "tebaida espiritual" (HUYSMANS, 1884, p. 9) sonha com uma certa Miss Urania, acrobata de compleição igualmente andrógina que ele havia visto atuando em um circo (HUYSMANS, 1884, p. 133-134). Assim como Des Esseintes, François aprecia as artes a ponto de querer trazê-la para a vida e vivê-la em sua plenitude de possibilidades estéticas. De maneira mais radical do que o protagonista do romance de Huysmans, François procura entender sua repulsa pelo corpo feminino na pura apreciação do corpo masculino (já que a mulher andrógina não o satisfaz). Ele louva as sensações evocadas pelo corpo viril na arte clássica, esquivando-se inclusive das figurações do feminino na arte:

No Louvre, fujo da Vênus de Milo, luxúria e não beleza, a tardo-grega das ilhas, pesada de Oriente e de decadência. A venustade longa das Dianas quase me satisfaz. Mas é diante dos Apolos, dos Antínoos, do hermafrodita de Velletri que as alegrias perfeitas, as alegrias inesgotáveis me detém. Também diante das esbeltezas entrelaçadas de certos grupos de lutadores. Dentre as mulheres pintadas do primeiro andar, apenas uma me interessa, aquela altiva Jeanne d'Aragon, cuja beleza sóbria é mencionada por Rafael. E, ainda assim, meu desejo a desfeminiza. (RYNER, 1903, p. 98)

Contemplando em si mesmo sua feminilidade ao admirar Baco e São João de Da Vinci, François, não se aceita plenamente, tampouco pode identificar sua própria natureza como feminina. Em sua análise sobre imagens subversivas e representações de perversão no fim do século XIX, Bram Dijkstra, ao citar as críticas de arte de Théophile Silvestre sobre o impressionismo ao redor de 1890, observa 
que o topos do espelho, além de indicativo de uma relativa liberdade sexual em relação à figuração do nu, revoca o mito de Narciso. A mulher - e em nosso caso o garoto efeminado - é tematicamente evocada como, nas palavras de Dijkstra, "mulher no espelho tanto quanto mulher como espelho", o que se aplica ao caso de François. Espécie de narciso aprisionado, François parece corresponder àquilo que se percebe como "epítome de efeminação, do efebo, do menino não ainda em posse de sua habilidade masculina de autotranscendência” (DIJKSTRA, 1986, p. 144), pois François não pode transformar-se. Está, portanto, condenado a ser, para sempre, a "menina que não vingou".

O desprezo de François para com as mulheres, portanto, não soa exatamente paradoxal, e sim voltado a si próprio e à sua autodepreciação, que oscila entre a admiração narcísica de sua própria beleza e seu reconhecimento enquanto homem feminino. No episódio da revolta contra o bedel do internato, que toma conhecimento da lista dos amantes da Reine Françoise, esta (François) afirma: "Ah! Aquele coitado do Signoret acreditara ter-me ofendido ao chamar-me de vadia. Eu ia escolher um título mais ignóbil, e dele me faria um título de honra” (RYNER, 1903, p. 110).

Assim, escondido nas "extremidades menos frequentadas do imenso pátio", onde "romãzeiras escalavam ao longo do muro" (RYNER, 1903, p. 30), em um claro simbolismo de seu desejo descontrolado, François se entrega de bom grado à proscrição, escondido nesta delimitação geográfica daquele microcosmos do colégio interno: um espaço outro que opera isoladamente, embora ali a vida decorra de modo tão velado com o mundo de fora, no que diz respeito à atividade sexual. No internato, a alienação espacial leva não apenas a uma realidade que toma ares extra-temporais e extra-espaciais, mas também a uma espécie de simulacro de identidade de gênero e de sexualidade. Assim, o conceito freudiano de narcisismo se concretiza nas sensações causadas por esses espaços:

\begin{abstract}
Eu saboreava naquele canto desconhecido todas as terríveis felicidades da proscrição. Através dos galhos espessos, eu olhava para o mar como um espelhamento múltiplo, ondulado e cantante: tal era o céu visto desde um sub-bosque, se a seda do céu estivesse movediça e rumorosa. Frequentemente, com meu espelho de bolso debaixo dos olhos, eu arrumava com lentas carícias meus cabelos ondulados, sorria para minha lindeza e repetia para mim mesmo, como uma declaração de amor: "Maricas! Ah! bela maricas..." (RYNER, 1903, p. 31)
\end{abstract}

A sede do leitor por um provável diagnóstico psicológico é então extinta pelo próprio François, sendo ele um amante das palavras e de si próprio:

Talvez houvesse certo narcisismo naquela admiração por mim mesmo. Creio que houvesse sobretudo
outra coisa. Pois eu pronunciava as palavras comovidas com uma voz que nunca era a minha voz. Dei-
me conta disso rapidamente, e tornou-se um jogo inquieto, o de me perguntar: "Que voz acaba de me
amar?" Eu procurava. Parecia-me que eu tinha imitado inconscientemente o sotaque de algum dos mais
grandes ou de algum dos mais jovens. E eu dizia: "amo Émile Pérol" ou "amo Paul Marchal.” Às vezes
eu me aplicava em tomar a voz de um ou de outro. Mas na maioria das vezes eu não premeditava minha
imitação. E, de repente, uma entonação me detinha: ela pertence a este aqui, àquele lá, a um belo que
me atraia, a um feio que me dava medo, ao próprio Romanes ou até ao bedel. (RYNER, 1903, p. 31)

A identidade feminina de François havia sido declarada por todos os alunos, que passaram a darlhe um terceiro apelido: Mamselle Françoise ("Senhorita Francisca", em uma abreviação do pronome de tratamento seguido do nome "François" no feminino). Revela-se aqui não somente mais uma corroboração de sua efeminação, na época indissociável da sexualidade ou da identidade de gênero, 
mas também o desprezo daqueles que o apelidam no feminino em uma sociedade sexista ou, ainda - e principalmente - uma desculpa para os alunos poderem buscar o prazer homossexual atribuindo ao amante o gênero biológico oposto com a intenção de se eximirem de culpa. Daí se explica o apelido que dá intitula o romance, e os outros apelidos, que até agradam François por fazerem com que ele se sinta desejado e satisfeito com seu a projeção de seu narcisismo no feminino. "Mamselle Françoise", por exemplo, "não o desagrada absolutamente" e "la fille manquée” lhe agradava muito (RYNER, 1903, p. 29):

Havia neste último apelido um quê de suave, de terno, de enfermo também, que a mim parecia exprimir deliciosamente minha graça frágil. Claro, eu não analisava. Mas frequentemente eu me escondia para mirar-me num espelho portátil murmurando “Maricas!”. E eu sorria, emocionado. E não estava de olhos molhados, mas - oh! estranha impressão, e que frequentemente encontrei por detrás de meus sorrisos - tive a impressão de que meus olhos choravam, do outro lado, do lado interior, lágrimas refinadas. (RYNER, 1903, p. 29)

Em outro momento, François confessa que o apelido la fille manquée, apesar de carregar uma deliciosa nostalgia, lhe era às vezes desagradável de escutar, não pelas palavras, mas, novamente, pela forma que estas eram proferidas: "Alguns tinham maneiras tão desprezíveis de me soprar [esse nome] ou maneiras tão imundas, tão beiçudas, tão gordurosas de me soprá-lo na orelha” (RYNER, 1903, p. 29). Dividido entre sua imagem através do outro, sem compreender sua própria identidade, o narcisismo se apresenta de forma nebulosa para François como um reconhecimento tortuoso de si enquanto feminino, tanto na visão que ele tem de si próprio quanto na visão que os outros lhe atribuem.

\section{CONCLUSÃO}

Permanece a dúvida anteriormente levantada por Tessé: François é homossexual e/ou transexual? Sendo a personagem uma criação de ficção (e não uma pessoa real), sendo o romance uma obra de arte (e não um tratado de medicina psiquiátrica), François reflete a complexa relação entrelaçada entre ciência, estética e progresso daquele século em oscilação entre o positivismo e o ocultismo, entre o erotismo e o misticismo. Porém, ainda assim, aquele foi um século fortemente preso por noções bem estabelecidas de masculino e feminino, duplamente fundado sobre a burguesia crescente e o cristianismo decrescente. Evidência disso é a associação direta do homossexual masculino ao feminino, segundo as classificações do Dr. Laupts. O não-pertencimento de François ao gênero com o qual se identifica é concretizado na sua própria experiência de escrita:

Talvez eu devesse esperar para delinear um quadro dos costumes que me cercavam no momento em que compreendi. Mas qual é esse momento? Os escritores, vejo muitíssimo bem, tão somente escrevem convenções. Se um deles contasse minha história, ele resumiria em um diálogo a lenta revelação, ou talvez associaria a um detalhe qualquer um valor significativo que ele tivesse, menos do que os outros, e que não poderia ter mais do que os outros. A arte de escrever não seria senão a arte de condensar as brumas longínquas e fazê-las passarem por rochedos? (RYNER, 1903, p. 22-23)

Assim, na compreensão de François, o termo fille manquée soa como uma litote, figura de linguagem tão presente na fraseologia francesa, através qual a negação, longe de cumprir sua função original, parece amplificar o sentido contrário daquilo que nega. A julgar pela relação de François com as palavras, a linguagem e a literatura, atestadas no começo de seu relato, podemos inclusive compreender 
a sexualidade de François como uma litote, como uma negação que, ao invés de negar, ressalta o seu oposto. Sua saúde precária será prejudicada quando ele se entrega a seus prazeres com volúpia que toma proporções hiperbólicas. Por fim, a própria estrutura litótica da expressão fille manquée acentua mais o fato de François ser biologicamente um homem, cuja identidade de gênero é feminina, do que propriamente uma "quase-mulher" ou "menina que não vingou”, em toda sua identidade trans que ele vislumbra em si e que os outros atestam nele.

Tomemos a liberdade de recordar, a título de conclusão, o ensaio Le Massacre des Amazones (1890?), do mesmo Ryner, a saber, uma passagem na qual o autor faz uma reflexão sobre o gênero, não de uma personagem, mas da própria linguagem literária: "A prosa poética, devido à sua jovem graciosidade e como inacabada, devido à liberdade de seu lirismo equívoco, é um gênero feminino, assim como no teatro o travestimento [les travestis] são empregos femininos" (RYNER, 1890?, p. 113). Semelhantemente, os traços da prosa de François, tão andróginas em gênero - identitário e literário anunciam a formação de uma identidade poética trans, bem como uma identidade de gênero que só se permitiria florescer muitas décadas depois.

\section{REFERÊNCIAS}

BUTLER, Judith. Gender Trouble. Nova Iorque: Routledge, 2007 [1990].

DIJKSTRA, Bram. Idols of Perversity: Fantasies of feminine evil in fin-de-siècle culture. Nova Iorque/Oxford: Oxford University Press, 1986.

FAURE, Sébastien (Org.), Encyclopédie Anarchiste (A-C). Éditions des Équateurs: Sainte-Marguerite-surMer, [1925-1934] 2013.

FREUD, Sigmund. Obras completas XI: Cinco lições de psicanálise, Leonardo da Vinci e outros escritos. 1910 [1909]. Disponível em: http://psicanalisebiblica.blogspot.com/2017/02/freud-obras-completas-xi.html. Acesso em 22/02/2021.

FREUD, Sigmund. Obras completas XVII (7): Uma criança é espancada - uma contribuição aos estudos da origem das perversões sexuais. 1919. Disponível em: http://www.freudonline.com.br/livros/volume-17/ vol-xvii-7-uma-crianca-e-espancada-uma-contribuicao-ao-estudo-da-origem-das-perversoes-sexuais-1919/. Acesso em 26/02/2021.

GASPODINI, Ícaro B.; GOMES DE JESUS, Jacqueline. "Heterocentrismo e Ciscentrismo: Crenças de superioridade sobre orientação sexual, sexo e gênero". Revista Universo Psi. Taquara, 2020, 1(2), p. 33-51.

HUYSMANS, J.-K. À rebours. Paris: Crès, 1922 [1884].

LAUPTS, G. Saint-Paul (Dr.). L'homosexualité et les types homosexuels: nouvelle édition de Perversion et perversités sexuelles. [Prefácio de Émile Zola]. Paris: Vigot Frères Éd., 1910.

LOMBROSO, Cesare. La Femme criminelle et la prostituée. Grenoble: Jerôme Million, 1991 [1895].

RENNEVILLE, Marc. "Un cranio che fa luce? Il racconto della scoperta dell'atavismo criminale." Il Museo di Antropologia criminale 'Cesare Lombroso'. Milão: Libreria UTET, 2013, p 107-112.

RODOVALHO, Amara Moira. “O cis pelo trans”. Revista Estudos Feministas, vol. 25, n. 1, 2017. Florianópolis, jan/abr, 2017. 
RYNER, Han. La Fille manquée. Montpellier: GayKitchCamp [GKC], 2013.

RYNER, Han. Le Massacre des Amazones. Paris: Chamuel Éditeur, 1890 (?).

TESSÉ, Nicolas. “Chronique: Han Ryner et La Fille manquée.” Disponível em: http://nicolastesse. portfoliobox.me/la-fille-manque 2014. Acesso em 21/02/2021. 